\title{
Atrioventrikuláris, egyelektródás, lebegő pitvari dipólussal rendelkező defibrillátorok (DX ICD) a klinikai gyakorlatban
}

\author{
Németh Marianna', Zima Endre1, Duray Gábor Zoltán², Balázs Tibor³, \\ Vámos Máté ${ }^{4}$
}

\author{
1Semmelweis Egyetem, Városmajori Szív- és Érgyógyászati Klinika, Budapest \\ ${ }^{2}$ Magyar Honvédség Egészségügyi Központ, Kardiológia Osztály, Budapest \\ ${ }^{3}$ Biotronik Hungária Kft., Budapest \\ ${ }^{4}$ Szegedi Tudományegyetem, ÁOK, Belgyógyászati Klinika, Szeged
}

Levelezési cím:

Dr. Vámos Máté, PhD, med. habil., Szegedi Tudományegyetem, Belgyógyászati Klinika, Elektrofiziológiai Részleg, 6725 Szeged, Semmelweis u. 8., e-mail: vamos.mate@gmail.com

A beültethető kardioverter-defibrillátorok (ICD) kimagasló terápiás lehetőséget biztosítanak a hirtelen szívhalál megelőzésében. Az ICD-k a malignus kamrai ritmuszavarok kezelésén túl további funkciókkal bővíthetők, javítva így a szívritmuszavarral élő, illetve szívelégtelenségben szenvedő betegek morbiditását és mortalitását. Jól ismert ugyanakkor, hogy az elektródák számának növekedésével a lehetséges komplikációk száma is növekszik. Az atrioventrikuláris, egyelektródás, lebegő pitvari dipólussal rendelkező defibrillátor rendszer (DX ICD), lehetővé teszi a pitvari érzékelés előnyeinek megtartását, további elektródák beültetése nélkül. Minden lehetséges előny szükségszerű feltétele a megbízható és stabil pitvari érzékelés. A DX-készülékek legújabb generációja, speciális pitvari jelerősítő segítségével, stabil és megfelelően magas pitvari jeleket tud biztosítani a hosszú távú utánkövetés során is. Ez a tulajdonság alapvető fontosságú a pitvari ritmuszavarok korai detekciója, illetve a pitvari és kamrai ritmuszavarok korrekt diszkriminációja során; a CRT-DX-rendszer esetén pedig a megfelelő pitvar-kamrai és kamrák közötti szinkronitás fenntartásához szükséges. Jelen közlemény szerzőinek tollából a közelmúltban, rangos nemzetközi folyóiratban jelent meg egy részletes összefoglaló tanulmány, amely a DX ICD-technológia klinikai előnyeit és lehetséges hátrányait foglalta össze az elérhető irodalmi adatok alapján. Ezúttal a hivatkozott tanulmány legfontosabb következtetéseit, a hazai vonatkozásokat, illetve az ICD-készülék kiválasztását támogató, evidenciákon nyugvó döntési algoritmust foglaltuk össze a magyar nyelvű olvasóközönség számára.

Kulcsszavak: ICD, Beültethető kardioverter defibrillátor, Egyelektródás ICD, VDD, DX, 2 elektródás CRT-D, CRT-DX

Clinical utility of the atrioventricular, single-lead defibrillator systems with a floating atrial dipole (DX ICD): an executive summary

Implantable cardioverter defibrillators offer preeminent therapeutic option for the prevention of sudden cardiac death. Beyond the treatment of malignant arrhythmias, ICDs can be expanded with additional functions to further improve morbidity and mortality of patients suffering from arrhythmias and heart failure. It is well known that the increase in the number of electrodes directly increases the risk of complications. The single-lead ICD system with a floating atrial dipole (DX ICD) preserves atrial sensing without the need to implant an additional lead. All advantages of the system are based on reliable and stable atrial sensing. In the current generation of DX devices, the specially filtered atrial signal seems to be high enough and stable over time. This feature is crucial in the early detection of atrial arrhythmias and in a correct discrimination between different forms of tachycardia's to prevent inappropriate ICD therapy, furthermore, in achieving an optimal atrioventricular and interventricular synchrony in patients with a two-lead CRT-DX system.

A detailed review was recently published by the authors of the current paper in a prestigious international journal summarizing the clinical advantages and potential disadvantages of DX ICD technology based on the available literature. This time we summarized the most important conclusions of the cited study, the domestic aspects and the proposed, evidence-based algorithm of proper ICD selection for the Hungarian physicians.

Keywords: ICD, Implantable cardioverter defibrillator, Single-lead ICD, VDD, DX, Two-lead CRT-D, CRT-DX

A kézirat 2021. 04 11-én érkezett a szerkesztőségbe, 2021. 06. 10-én került elfogadásra. 


\section{Bevezetés}

A beültethető kardioverter-defibrillátorok (ICD-k) jelentősen csökkentik a morbiditást és a mortalitást a szívritmuszavarokkal élő, illetve szívelégtelenségben szenvedő betegek esetén. Az elmúlt években, a technológia fejlődésének köszönhetően, ezen eszközök mind biztonságosabbá és hatékonyabbá váltak, továbbra is fennáll azonban a súlyos szövődmények előfordulásának veszélye, különösképpen a transzvénásan beültetett elektródák esetén. Ismert tény, hogy a beültetett elektródák számával nemcsak a műtéti és a fluoroszkópiás idő, de a szövődmények kockázata is nő, különös tekintettel a trombózis és a fertőzés veszélyére (1-4). Ezen szövődmények elkerülésére különböző technológiai fejlesztések történtek az életet veszélyeztető szívritmuszavarok eszközös terápiája területén. A szubkután implantálható kardioverter-defibrillátor (S-ICD) például transzvénás elektróda nélküli kezelési alternatívát kínál, jóllehet alkalmazása egyelöre csak olyan betegeknél jön szóba, akiknél nem áll fenn bradycardia vagy antitachycardia miatti ingerlési igény, illetve reszinkronizációs kezelés indikációja (5). Az egyelektródás pitvari lebegő dipólussal rendelkező DX-defibrillátor-rendszer viszont lehetőséget biztosít a pitvari tevékenység megfelelő érzékelésére, további pitvari elektróda beültetése nélkül.

A jelen közlemény szerzőinek tollából a közelmúltban, rangos nemzetközi folyóiratban jelent meg egy részletes összefoglaló tanulmány, amely a DX ICD-technológia klinikai előnyeit és lehetséges hátrányait mutatja be (6). A következőkben a hivatkozott tanulmány legfontosabb konklúzióit, a hazai vonatkozásokat, illetve az ICD-készülék kiválasztását támogató, evidenciákon nyugvó döntési algoritmust foglaljuk össze magyar nyelven.

\section{A DX-technológia ismertetése}

A DX (Diagnostic eXtension) készülék olyan ICD, amely egyetlen kamrai elektródából áll, az elektróda pitvari részén azonban úgynevezett lebegő dipólus érzékelővel is rendelkezik (1. ábra). A technológia a 2000-es évek elején a Biotronik cég (Biotronik, SE \& Co., Berlin, Németország) által, „A+ ICD” néven került bevezetésre, majd 2011-től a továbbfejlesztett, „DX” terminológiával jelölt változat került forgalomba (7). Az újabb technológiai fejlesztéseknek köszönhetően a kételektródás CRT-DX-készülékek is elérhetővé váltak, amelyek egy pitvari dipóllal rendelkező jobb kamrai ICD-elektródából és egy bal kamrai, sinus coronarius elektródából épülnek fel. A DX ICD-elektróda mostanra DF-1-es és DF-4-es csatlakozóval is elérhető (2. ábra), az elektródavég és a pitvari dipol közötti távolság tekintetében pedig a 15 és $17 \mathrm{~cm}$-es verziókból lehet választani. A megfelelő pitvari érzékelést az optimalizált pitvari elektródatávolság és egy jelerősítő (pre-amplifier) se-

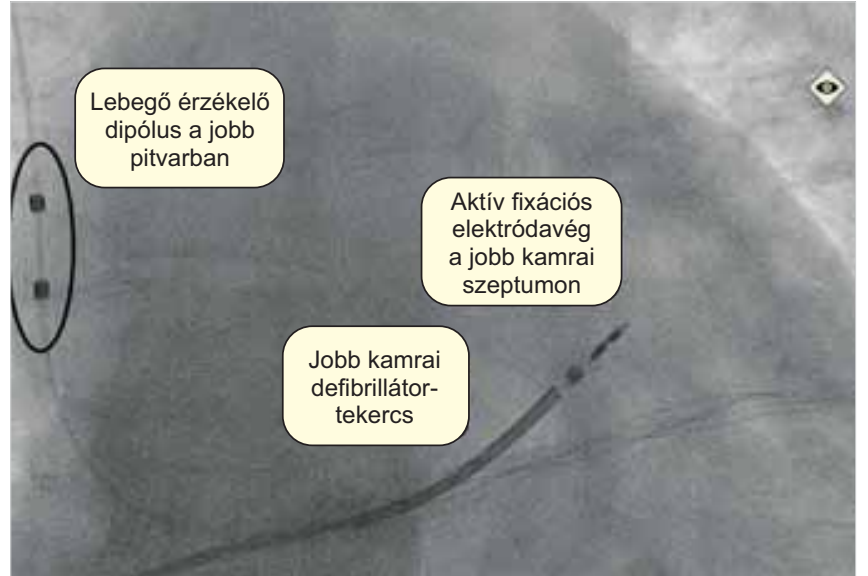

1. ÁBRA. Az atrioventrikuláris, egyelektródás, lebegő pitvari dipólussal rendelkező defibrillátor (DX ICD) antero-posterior röntgenképe

gíti, amely utóbbi akár négyszeresére is növelheti az érzékelt pitvari jelet. A rendszerhez tartozik még egy jeláteresztő szűrő (wider bandpass filter), amely a pitvari aktivitástól független jeleket és zajokat szűri ki.

\section{A DX ICD-technológia lehetséges klinikai elönyei és hátrányai \\ AV-szekvenciális ingerlési lehetóség}

Amerikai regiszteradatok alapján, a kétüregü ICD-beültetésben részesülő betegek csupán 40\%-ánál áll fenn a pitvari ingerlés valós indikációja (8). A szövődményráta ugyanakkor bizonyítottan magasabb a kétüregü készülékek beültetése esetén, összehasonlítva az együregü készülékekkel (1-3, 8, 9). Ez elsősorban abból adódik, hogy a pitvari elektródák gyakrabban mozdulhatnak ki, mint a kamrai elektródák (10). Tünetes sick-sinus-szindróma esetén pitvari ingerlés szükséges, így a pitvari elektróda beültetésének indikációja egyértelmü; ilyen esetekben a DX ICD nem szolgálhat terápiás megoldásként. Több vizsgálat is bizonyította ugyanakkor, hogy a szükségtelen pitvari ingerlés káros is lehet, összefüggésbe hozható például pitvarfibrilláció kialakulásával (11). A klinikai gyakorlatban, mérsékelt fokú atrioventrikuláris (AV) és/vagy kamrai ingerületvezetési zavarral rendelkező betegek esetén (pl.: elsőfokú AVblokk, jobb Tawara-szár-blokk, aspecifikus QRS-kiszélesedés), amikor a beültető orvos hosszú távon magas fokú AV-vezetési zavar potenciális rizikójával számol, gyakrabban alkalmazzák a kétüregü készülékeket (8). Abszolút pitvaringerlés indikációja nélkül, a fenti esetekben a DX ICD optimális választás lehet.

\section{Kardiális reszinkronizációs terápia 2 elektródán keresztül (CRT-DX-rendszer)}

Izgalmas klinikai kérdés, hogy vajon a kardiális reszinkronizációs kezelés biztonságosan kivitelezhető-e 


\section{DF-1/ IS-1 típus:}

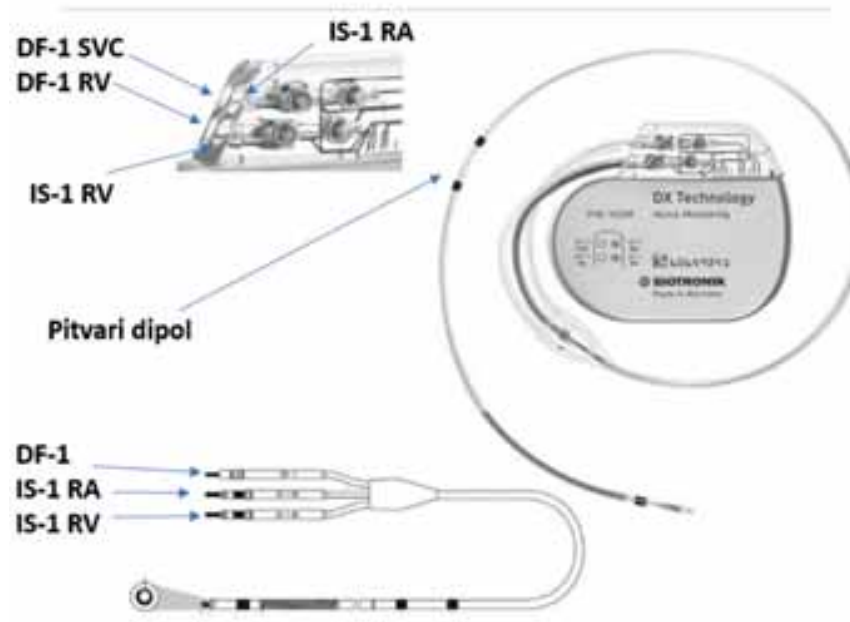

Összesen 4 csatlakozó furat az elektródához:

- 2 db DF-1 a sokkelektróda végzódéshez

- $1 \mathrm{db}$ IS-1 a pitvari jelhez (IS-1 RA)

$1 \mathrm{db}$ IS-1 a kamrai jelhez (IS-1 RV)

Röviditesek: RA: jobb pitvar, RV: jobb kaenra, SVC: superior vena cava, P/S: pace/sense

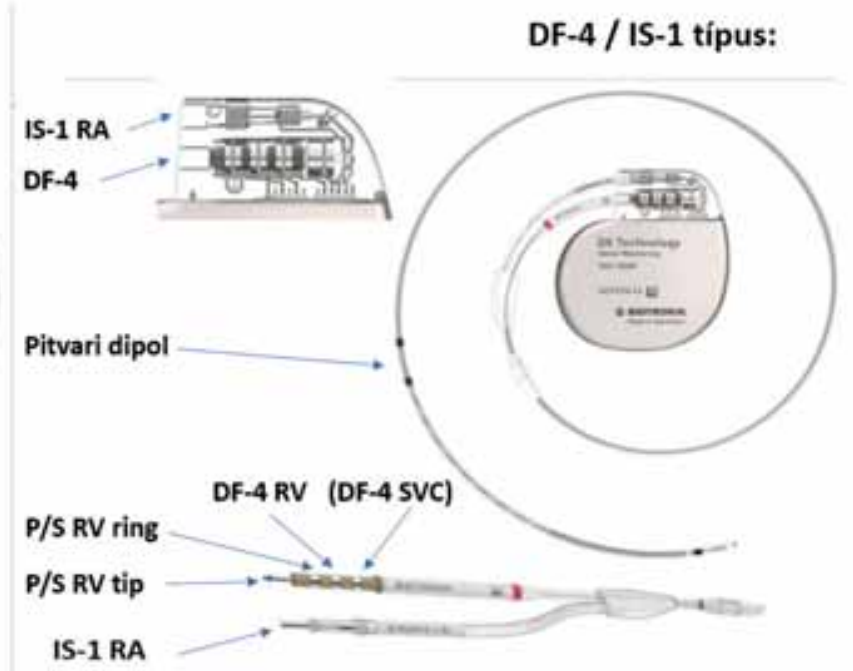

Összesen 2 csatlakozó furat az elektródához:

- $1 \mathrm{db}$ DF-4 a sokkelektróda végzödéshez és a kamrai jelhez (P/S RV)

- $1 \mathrm{db}$ IS-1 a pitvari jelhez (IS-1 RA)

2. ÁBRA. DX ICD csatlakozó típusok

2 elektródával (CRT-DX-rendszer). Ezen a területen egyelőre kevés tapasztalat és evidencia áll rendelkezésre. Biffi és munkatársai 25 hagyományos, 3 elektródás CRT-D-készüléket viselő beteg klinikai kimenetelét hasonlították össze 12 olyan betegével, akik CRT-DXrendszer implantációban részesültek (12). A 3 éves utánkövetési periódus során egy betegnél sem vált szükségessé pitvari ingerlés és nem fordult elő klinikai következménnyel járó pitvari undersensing sem. A „Sentus QP-Extended CRT Evaluation with Quadripolar Left Ventricular Leads" vizsgálat alcsoport-analízisében pedig 120 CRT-DX-et viselő beteget hasonlítottak össze 120 olyan beteggel, akik hagyományos 3 elektródás CRT-D-rendszerrel éltek. Ebben a retrospektív vizsgálatban, a CRT-DX-rendszer a klasszikus, 3 elektródás CRT-készülékekkel megegyező klinikai választ biztosított, alacsonyabb szövődményráta mellett, amely legfőképpen a jobb pitvari elektróda elmozdulásának a hiányából adódott (13).

A pitvari elektróda típusától függetlenül, a magas arányú reszinkronizáció biztosításához elengedhetetlen a pitvarfibrilláció megbízható felismerése és a megfelelő üzemmódváltás. Permanens pitvarfibrillációban szenvedő betegek esetén pitvari elektróda általában nem kerül beültetésre CRT-implantáció során, jóllehet, az esetek akár 10\%-ában a sinusritmus spontán visszatérhet (14). Ilyenkor előnyös lehet a CRT-DX-rendszer a pitvari érzékelés lehetősége miatt, mert a pitvar-kamrai szinkronitás újabb reoperáció nélkül is biztosítható.

Érdemes még kitérni a CRT upgrade-beavatkozások problémájára is, hiszen jól ismert, hogy az elektródák számának növekedésével a lehetséges szövődmények száma is emelkedik (15). Ez alapján, egy DX ICD-rendszerről történő CRT-upgrade - amennyiben a pitvari érzékelés tartós stabil volta már igazolható - kevesebb szövődmény lehetőségét hordozza magában. Az erre vonatkozó tapasztalatok egyelöre szintén korlátozottak. Az egyik legnagyobb esetszámú, DX ICD-s betegeket utánkövető regiszterben 140-ből 1 betegnél volt szükséges CRT-upgrade, amely mütétet a 2 elektródás CRTDX-rendszer beültetésével sikeresen elvégezték (16). Minden bíztató eredmény ellenére, további, nagy betegszámú, randomizált vizsgálatok szükségesek a de novo CRT-DX-rendszer és az erre történő upgrade hosszú távú biztonságosságának igazolására.

\section{Tachycardia-diszkrimináció az inadekvát ICD-terápia megelözésére}

A szupraventrikuláris és kamrai ritmuszavarok elkülönítése az egyik legizgalmasabb, de sokszor a legtöbb kihívással járó területe a klinikai elektrofiziológiának. Bár logikusnak tünne, hogy a kétüregű készülékek pontosabb ritmuszavar-diszkriminációt biztosíthatnak, az erre vonatkozó tudományos bizonyítékok ellentmondásosak (3. ábra) (17-19). Ez alapján a HRS/EHRA/ APHRS/SOLAECE szakértői konszenzus a pontosabb SVT-VT-diszkriminációt nem tekinti a kétüregű ICD-választás indikációjának az együregű készülékkel szemben (20). A pitvari érzékelővel is rendelkező, de egyelektródás DX ICD-rendszer azonban, az együregü diszkriminációs algoritmusok mellett, kétüregű diszkriminációs lehetőséget is kínál (SMART algoritmus). 


$$
(n=977)
$$

PR Logic (DDD)

Wavelet (WI) $(n=100)$

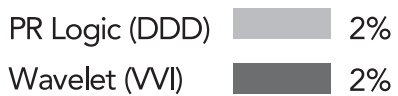

$(n=462)$

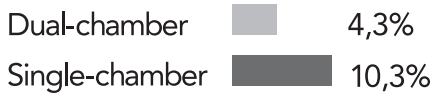

3. ÁBRA. Az inadekvát ICD-terápia gyakoriságának összehasonlítása egy- (VVI) és kétüregű (DDD) ICD-k között, különböző klinikai vizsgálatokban

Néhány korai tanulmányban inadekvát terápiát az esetek 7,8-8,6\%-ában figyeltek meg ezen készülékekkel, a követés időtartamától függően $(21,22)$. Újabb közleményekben ez az arány csak 0,83\% volt, az átlagosan 1,3 éves utánkövetés során (13). Egy további, 150 DX ICDvel élő beteggel végzett vizsgálatban egyáltalán nem fordult elő inappropriate terápia a 12 hónapos utánkövetés alatt (23). Kurt és munkatársai által végzett egycentrumos, prospektív vizsgálatban 212 konszekutív beteg adatait hasonlították össze, akik hagyományos(VVI) vagy DX együregü ICD-beültetésen estek át. $A z$ inappropriate terápiák előfordulása a DX-csoportban szignifikánsan alacsonyabb volt a VVI-csoporthoz képest $(1 / 77(1 \%)$ vs. $12 / 135(9 \%), p=0,028)(24)$.

A jelenleg forgalomban lévő DX ICD-rendszerekben mind az együregü, mind a kétüregü diszkriminációs algoritmusok elérhetők (MorphMatch, SMART). Egyelőre azonban nem teljesen egyértelmü, hogy melyik algoritmus programozása javasolt elsődlegesen, mivel a Biotronik két diszkriminációs technológiáját közvetlenül összehasonlító vizsgálat ezen a területen még nem áll rendelkezésre.

\section{A pitvari ritmuszavarok korai felismerése}

A pitvarfibrilláció (PF) a 65 év feletti népesség körében az egyik leggyakrabban előforduló szívritmuszavar, amely az életkor előrehaladtával exponenciálisan nő. Jelentősen megnöveli a stroke-, tromboembóliás szövődmények-, valamint a szívelégtelenség okozta halálozás kockázatát, rontja az életminőséget, fokozza a hospitalizációk számát (25). Tartós PF mellett nagyjából ötszörösére emelkedik a stroke-kockázat, de már az ennél lényegesen rövidebb, csak beültethető eszközzel dokumentált, ún. szubklinikus PF-epizód (SCAF) mellett is $0,8-1 \%$-os stroke-rizikóval kell számolnunk (26). Ezen szövődmények megelőzése céljából kiemelten fontos a néma pitvarfibrilláció mielőbbi felismerése. A beültethető kardiális eszközökkel élő betegekben végzett vizsgálatok alapján, a pitvari elektródával rendelkező készülékek esetén, a szupraventrikuláris ritmuszavar incidenciája, kezdete és időtartama pontosan, százalékos arányban is meghatározható, valamint tartós PF esetén az antiaritmiás- és az antikoaguláns kezelés szükségessége és előbbinek a hatékonysága is megítélhető.
A prospektív, multicentrikus SENSE-vizsgálatban 150 olyan DX ICD-vel élő beteget vizsgáltak, akik anamnézisében nem szerepelt PF. A 12 hónapos utánkövetés eredményeit hagyományos együregü- és kétüregű ICD-vel élő betegek adataival hasonlították össze. A SCAF előfordulási aránya szignifikánsan magasabb volt a DX-csoportban az együregü készülékkel élő betegekéhez képest ( $13 \%$ vs. $5,3 \%, p=0,026)$, de nem különbözött szignifikánsan a kétüregü csoporttól (13\% vs. $13 \%, p=1,00)(23)$. A legutóbb közzétett, prospektív, multicentrikus THINGS-regiszterben a pitvari érzékeléssel ellátott DX ICD-s csoport betegei között a pitvari tachyarrhythmia felismerésének valószínúsége csaknem négyszer nagyobb volt, összehasonlítva a konvencionális együregü ICD-vel élő páciensekhez képest (11,4\% vs. 3,6\% 2 éven belül, korrigált HR: 3,85, 95\%; Cl: 1,58-9,41, p=0,003) (16).

$A z$ ismertetett vizsgálatok adatai alapján a DX ICD optimális választás olyan magas stroke-rizikóval rendelkező betegek esetében, akiknél az emelkedett $\mathrm{CHA}_{2} \mathrm{DS}_{2}-$ VASc score alapján - pitvari ritmuszavar detekciója esetén - tartós antikoaguláns kezelés indikációja állna fent. A folyamatban lévő DX-AF-vizsgálatból arra a kérdésre is választ kaphatunk a közeljövőben, hogy milyen további előnyt jelent a DX-rendszer telemonitorozással való kiegészítése a PF, illetve SCAF korai felismerésében (clinicaltrials.gov azonosító: NCT03110627).

\section{A DX-rendszer ismert és lehetséges kockázatai}

Minden lehetséges előny szükségszerü feltétele a megbízható és stabil pitvari érzékelés. A DX-rendszer számos átalakításon ment keresztül az elmúlt két évtizedben, a pitvari érzékelés optimalizálása érdekében. Az eszközök jelenlegi generációjában a pitvari jel átlagos amplitúdója 1,8 és 8,7 mV között mozog a különböző publikációkban, és stabilnak bizonyult hosszú távú utánkövetés során is $(16,21-23,27)$.

A stabil pitvari jelérzékelés ellenére több esetben beszámoltak a ritmuszavarok téves diszkriminációjáról, amelynek oka az esetek túlnyomó részében a kamrai jel pitvari csatornán történő far-field oversensing-je volt $(16,23,27)$. Safak és munkatársai által végzett igen alapos, minden beteg telemetriás utánkövetési adatait kritikusan elemző vizsgálatában 7,5\%-ban történt in- 
appropriate ICD-müködés (27). Ezen felül, 3 betegnél, a relatív lassú kamrai tachycardia-epizódokat a készülék tévesen szupraventrikuláris ritmuszavarnak minősítette, így nem történt megfelelő terápialeadás. A téves detekció oka a kamrai blanking periódus alatti pitvari undersensing volt, amelynek során a készülék egy beépített biztonsági funkció következtében automatikusan kétüregű diszkriminációról együregüre váltott (onset/ stability). Ezzel a megoldással ugyan elvben csökken az inadekvát terápia rizikója, ha azonban az algoritmusváltás zajló kamrai ritmuszavar közben történik, a ritmuszavar onset kritériumai nem teljesülnek és a ritmuszavar terápia nélkül maradhat (27).

A perioperatív paraméterekkel kapcsolatos adatokat tekintve, a beavatkozási időben, a fluoroszkópiás időben és a perioperatív szövődmények számában sem mutatkozott lényeges különbség a DX-rendszernél a hagyományos VVI ICD-implantációkhoz képest (23, 24). Minden DX típusú készülék alkalmas telemonitorozásra, amely lehetőséget nyújt a fent részletezett lehetséges kockázatok korai felismerésére és kezelésére. Van még néhány nyitott kérdés, amelyekről érdemben nyilatkozni csak további vizsgálatokat követően lehetséges, úgymint az elektródák hosszú távú tartóssága, eltávolíthatósága, vagy a rendszer költséghatékonysága.

\section{Magyarországi vonatkozások}

A DX-technológia először 2007-ben jelent meg Magyarországon az OEP-tender keretein belül. Az első rendszereket a Lexos $A+$ együregü defibrillátor és a Kentrox A+ pitvari érzékeléssel ellátott sokkelektróda együttesen alkotta. Termékváltás 2010-ben történt, az MR kondicionális Lumax 540 VR-T DX defibrillátor és Linox Smart ProMRI DX sokkelektróda szettel, majd ezt követően több, szintén MR kondicionális DX technológiás defibrillátor szett jelent meg a hazai betegellátásban; mint például az Iforia 5 VR-T DX a Linox Smart ProMRI DX elektródával, az Itrevia 5 VR-T DX a Protego ProMRI DX elektródával, Intica 5 VR-T DX a Plexa ProMRI DX elektródával. Jelenleg az Intica 5 VR-T DX, az Intica 5 Neo VR-T DX és a Rivacor 5 VR-T DX defibrillátorok, valamint a Plexa ProMRI DX elektródák érhetőek el Magyarországon az aktuális NEAK-tender keretein belül.

Az elmúlt 2 évre vonatkozó, hazai ICD-beültetések számait és azok típus szerinti megoszlási arányát a 4. ábrán tüntettük fel. Míg a de novo ICD-beültetések összesített számában 2020-ban, a nemzetközi trendhez hasonlóan, kisfokú csökkenés volt észlelhető hazánkban (2019-ben 1372; 2020-ban 1320 implantáció), amely főként a COVID-19-világjárvány hatásaival magyarázható, a DX típusú egyelektródás ICD-k felhasználási aránya az összes éves beültetés 7,8\%-áról $12,3 \%$-ra emelkedett $(+4,5 \%)$.

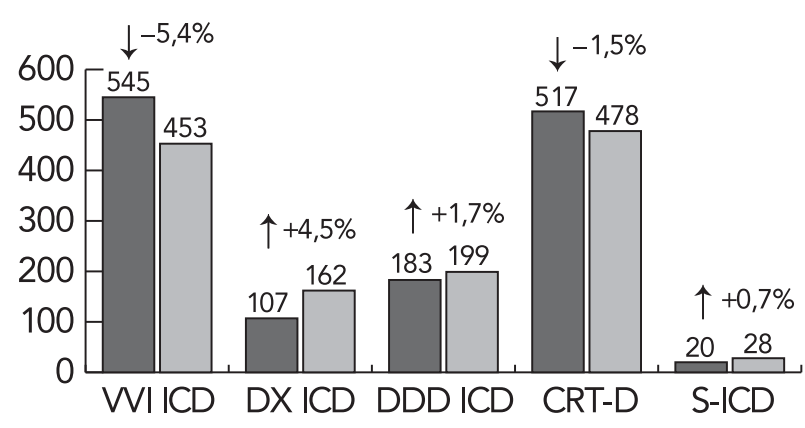

4. ÁBRA. Magyarországon 2019-ben és 2020-ban végzett, de novo ICD-beültetések típus szerinti megoszlása (a sötét oszlop jelöli a 2019-ben, a világos a 2020-ban végzett implantációkat)

\section{Javasolt do̊ntési pontok a megfelelö ICD-készůlék kiválasztásához}

A jelenlegi összefoglalóban, illetve az ennek alapjául szolgáló, részletes áttekintő tanulmányban (6) ismertetett legfontosabb tudományos bizonyítékok, valamint az érvényben lévő európai- és az amerikai kardiális reszinkronizációs terápiával és pitvarfibrilláció szűrésével kapcsolatos irányelvek $(20,25,28-30)$ alapján az alábbi kérdések átgondolását javasoljuk tervezett ICD-beültetés esetén:

Szükséges-e bal kamrai elektróda beültetése?

- Tünetekkel járó szívelégtelenség, LVEF $\leq 35 \%$ és BTSZB (QRS >130 ms).

- Tünetekkel járó szívelégtelenség, LVEF $\leq 35 \%$ és nem BTSZB (QRS >150 ms).

- Keskeny QRS, de LVEF 36-50\% és magas kamrai ingerlési igény várható.

Várhatóan szükség lesz-e pitvari ingerlésre?

- Klinikailag jelentős sick-sinus-szindróma (SSS) vagy kronotróp inkompetencia.

- Klinikailag jelentős sinus bradycardia, amely korlátozza béta-blokkoló-terápia elindítását vagy feltitrálását.

Várható-e az adott beteg esetében klinikai előny a pitvari érzékelés lehetőségétől?

- Terápiás következmény a néma pitvari ritmuszavar detekciója esetén.

- Permanens pitvarfibrilláció áll fent, de van esély a sinusritmus visszatérésére (pl. tervezett kardioverzió, abláció vagy spontán konverzió előfordulhat).

\section{Felmerülö CRT-D upgrade szükségessége esetén a korábban beültetett DX ICD-rendszer pitvari érzékelése megbízható-e?}

A beültetendő ICD típus kiválasztását támogató döntéshozatali folyamatot a 5. ábra mutatja be.

Természetesen a DX-technológia által nyújtott potenciális előnyök mellett figyelembe kell venni a rendelkezésre álló készülékek egyéb algoritmusait, speciális 


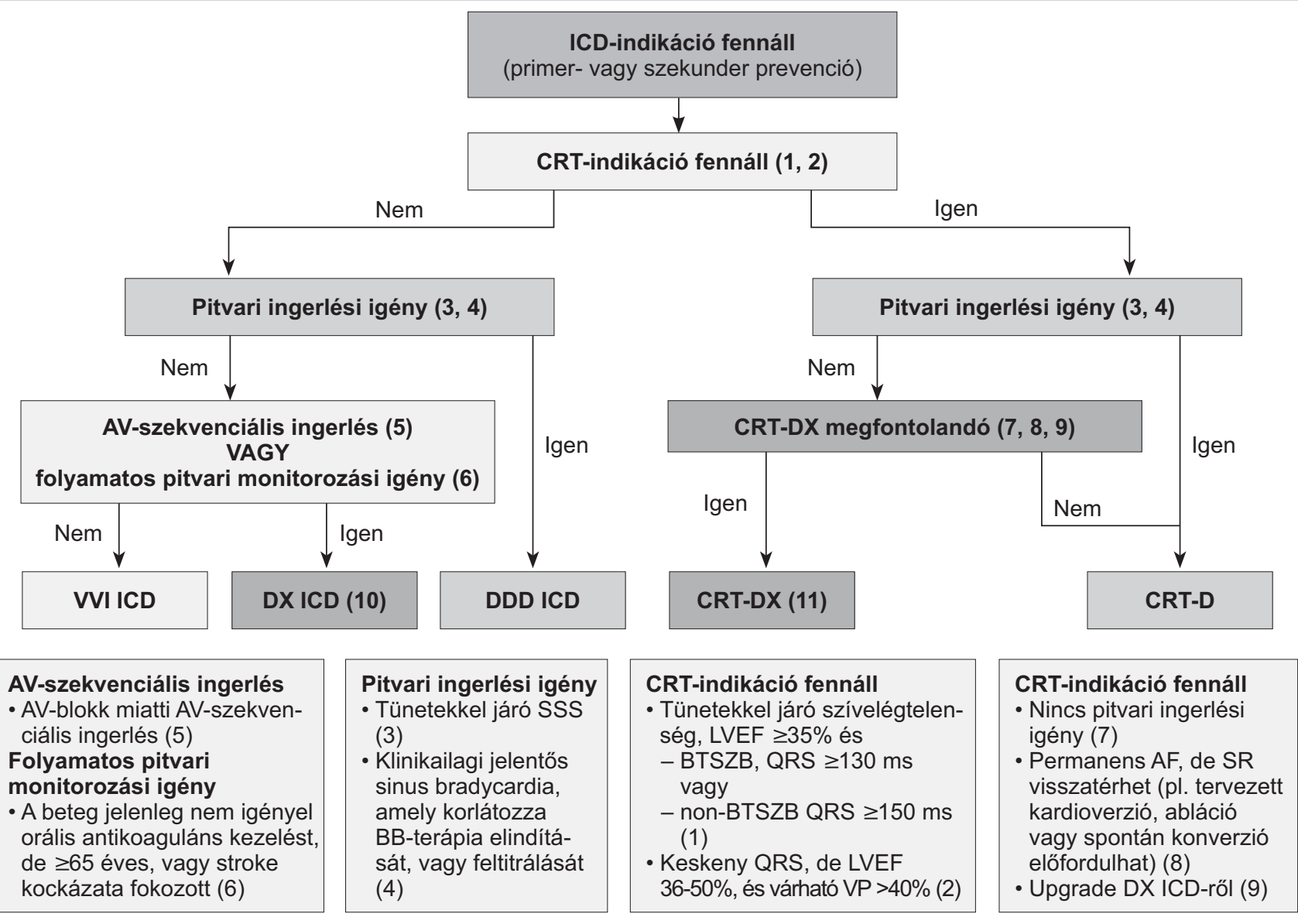

5. ÁBRA. A beültetendő ICD típus kiválasztását támogató döntéshozatali folyamatábra. Vamos et al. Trends Cardiovasc Med 2021; S1050-1738(21)00004-9. nyomán (6). 1. (28, 30); 2. (29, 30); 3. (20, 28, 29); 4. (28, 30); 5. (28, 29); 6. (16, 23, 25, 26); 7. (1-4, 7-11); 8. (14); 9. (15, 16); 10. (1-4, 7-11, 17-22, 24, 27); 11. (12, 13, 15, 16-18, 20)

funkciói nyújtotta lehetőségeket, a beteg fizikális állapotát, valamint a költségeket is. Minden esetben az adott beteg számára várhatóan legelőnyösebb készülék beültetése mellett kell döntenünk.

\section{Következtetések}

A DX ICD-rendszer az utóbbi években történt fejlesztéseknek köszönhetően, a lebegő pitvari dipólus érzékelő segítségével, megbízható, a kételektródás rendszerekkel egyenértékü ritmuszavar diagnosztikát tesz lehetővé. A pitvari elektrogramm segítségével a pitvari ritmuszavarok korai felismerése mellett lehetőség van a szupraventrikuláris és kamrai ritmuszavarok elkülönítésére, valamint AV-szekvenciális ingerlésre is. A DX-technológia szerepet játszhat a sugáridő és a mütéti idő csökkentésében, a perioperatív szövődmények kockázatának visszaszorításában, különös tekintettel a pitvari elektródabeültetéssel kapcsolatos komplikációkra. A jelenleg rendelkezésünkre álló tudományos bizonyítékok alapján, a DX ICD- és CRT-DX-rendszerek, körültekintően kiválasztott betegcsoportban, megfelelő alternatívái lehetnek a két-, illetve háromelektródás
ICD-knek, azonban ezen a területen további, nagy betegszámú klinikai vizsgálatok szükségesek.

\section{Nyilatkozat}

Dr. Németh Mariann tanácsadói/előadói szerződésben áll a Biotronik, a Boston Scientific, a MicroPort, és a Medtronic cégekkel. Dr. Zima Endre tanácsadói/előadói szerződésben áll az Abbott, a Biotronik, a Boston Scientific, az Innomed, és a Replant cégekkel. Dr. Duray Gábor Zoltán tanácsadói/ előadói szerződésben áll az Abbott, a Biotronik, a Medtronic, és a Replant cégekkel. Dr. Balázs Tibor a Biotronik Hungary Ltd. alkalmazottja. Dr. Vámos Máté tanácsadói/előadói szerződésben áll a Biotronik, a Medtronic, és a Minimal Invasive Technology Ltd. cégekkel.

\section{rodalom}

1. Chen BW, Liu Q, Wang X, et al. Are dual-chamber implantable cardioverter-defibrillators really better than single-chamber ones? A systematic review and meta-analysis. J Interv Card Electrophysiol 2014; 39: 273-80. https://doi.org/10.1007/s10840-014-9873-3

2. Vamos M, Erath JW, Benz AP, et al. Incidence of cardiac perforation with conventional and with leadless pacemaker systems: a sys- 
tematic review and meta-analysis. J Cardiovasc Electrophysiol 2017; 28: 336-46. https://doi.org/10.1111/jce.13140

3. Polyzos KA, Konstantelias AA, Falagas ME. Risk factors for cardiac implantable electronic device infection: a systematic review and meta-analysis. Europace 2015; 17: 767-77.

https://doi.org/10.1093/europace/euv053

4. Duray GZ, Schmitt J, Cicek-Hartvig S, et al. Complications leading to surgical revision in implantable cardioverter defibrillator patients: comparison of patients with single-chamber, dual-chamber, and biventricular devices. Europace 2009; 11: 297-302.

https://doi.org/10.1093/europace/eun322

5. Vámos $M$, Bári Zs, Bógyi $P$, et al. A szubkután ICD: indikációk, beültetés, utánkövetés, evidenciák. Cardiologia Hungarica 2017; 47: 290-295. https://doi.org/10.26430/chungarica.2017.47.4.290

6. Vamos M, Nemeth M, Balazs T, et al. Rationale and feasibility of the atrioventricular single-lead ICD systems with a floating atrial dipole (DX) in clinical practice (published online ahead of print, 2021 Jan 19). Trends Cardiovasc Med 2021; S1050-1738(21)00004-9. https://doi.org/10.1016/j.tcm.2021.01.003

7. Worden NE, Alqasrawi M, Krothapalli SM, et al. Two for the Price of One": a single-lead implantable cardioverter-defibrillator system with a floating atrial dipole. J Atr Fibrillation 2016; 8: 1396. https://doi.org/10.4022/jafib.1396

8. Dewland TA, Pellegrini CN, Wang Y, et al. Dual-chamber implantable cardioverter-defibrillator selection is associated with increased complication rates and mortality among patients enrolled in the NCDR implantable cardioverter-defibrillator registry. J Am Coll Cardiol 2011; 58: 1007-13. https://doi.org/10.1016/j.jacc.2011.04.039 9. Peterson PN, Varosy PD, Heidenreich PA, et al. Association of single- vs dual-chamber ICDs with mortality, readmissions, and complications among patients receiving an ICD for primary prevention. JAMA 2013; 309: 2025-34. https://doi.org/10.1001/jama.2013.4982 10. Ghani A, Delnoy PP, Ramdat Misier AR, et al. Incidence of lead dislodgement, malfunction and perforation during the first year following device implantation. Neth Heart J 2014; 22: 286-91.

https://doi.org/10.1007/s12471-014-0556-6

11. Fontenla A, Salguero $R$, Martinez-Ferrer JB, et al. Atrial rateresponsive pacing and incidence of sustained atrial arrhythmias in patients with implantable cardioverter defibrillators. Pacing Clin Electrophysiol 2016; 39: 548-56. https://doi.org/10.1111/pace.12856 12. Biffi M, Massaro G, Candelora A, et al. Less is more: can we achieve cardiac resynchronization with 2 leads only? Int J Cardiol 2017; 249: 184-90. https://doi.org/10.1016/j.ijcard.2017.09.189

13. Shaik NA, Drucker M, Pierce C, et al. Novel two-lead cardiac resynchronization therapy system provides equivalent CRT responses with less complications than a conventional three-lead system: results from the QP ExCELs lead registry. J Cardiovasc Electrophysiol 2020; 31: 1784-92.https://doi.org/10.1111/jce.14552

14. Gasparini M, Steinberg JS, Arshad A, et al. Resumption of sinus rhythm in patients with heart failure and permanent atrial fibrillation undergoing cardiac resynchronization therapy: a longitudinal observational study. Eur Heart J 2010; 31: 976-83.

https://doi.org/10.1093/eurheartj/ehp572

15. Vamos M, Erath JW, Bari Z, et al. Effects of upgrade versus de novo cardiac resynchronization therapy on clinical response and long-term survival: results from a multicenter study. Circ Arrhythm Electrophysiol 2017; 10: e004471.

https://doi.org/10.1161/CIRCEP.116.004471

16. Biffi $M$, Iori $M$, De Maria $E$, et al. The role of atrial sensing for new-onset atrial arrhythmias diagnosis and management in singlechamber implantable cardioverter-defibrillator recipients: results from the THINGS registry. J Cardiovasc Electrophysiol 2020; 31: 846-53. https://doi.org/10.1111/jce.14396

17. Gold MR, Ahmad S, Browne K, et al. Prospective comparison of discrimination algorithms to prevent inappropriate ICD therapy: primary results of the Rhythm ID Going Head to Head Trial. Heart Rhythm 2012; 9: 370-7. https://doi.org/10.1016/j.hrthm.2011.10.004 18. Friedman PA, Bradley D, Koestler C, et al. A prospective randomized trial of single- or dual-chamber implantable cardioverterdefibrillators to minimize inappropriate shock risk in primary sudden cardiac death prevention. Europace 2014; 16: 1460-8.

https://doi.org/10.1093/europace/euu022

19. Kolb C, Sturmer M, Sick $P$, et al. Reduced risk for inappropriate implantable cardioverter-defibrillator shocks with dual-chamber therapy compared with single-chamber therapy: results of the randomized OPTION study. JACC Heart Fail 2014; 2: 611-19.

https://doi.org/10.1016/j.jchf.2014.05.015

20. Wilkoff BL, Fauchier L, Stiles MK, et al. HRS/EHRA/APHRS/ SOLAECE expert consensus statement on optimal implantable cardioverter-defibrillator programming and testing. Heart Rhythm 2016; 13: e50-86. https://doi.org/10.1016/j.hrthm.2015.11.018

21. Safak E, Schmitz D, Konorza T, et al. Clinical efficacy and safety of an implantable cardioverter-defibrillator lead with a floating atrial sensing dipole. Pacing Clin Electrophysiol 2013; 36: 952-62.

https://doi.org/10.1111/pace.12171

22. Worden NE, Alqasrawi M, Mazur A. Long-Term Stability and Clinical Utility of Amplified Atrial Electrograms in a Single-Lead ICD System with Floating Atrial Electrodes. Pacing Clin Electrophysiol 2016; 39: 1327-34. https://doi.org/10.1111/pace.12967

23. Thomas G, Choi DY, Doppalapudi H, et al. Subclinical atrial fibrillation detection with a floating atrial sensing dipole in single lead implantable cardioverter-defibrillator systems: results of the SENSE trial. J Cardiovasc Electrophysiol 2019; 30: 1994-2001.

https://doi.org/10.1111/jce.14081

24. Kurt M, Jathanna N, Babady $M$, et al. Avoiding inappropriate therapy of single-lead implantable cardioverter-defibrillator by using atrial-sensing electrodes. J Cardiovasc Electrophysiol 2018; 29: 1682-9. https://doi.org/10.1111/jce.13736

25. Hindricks G, Potpara T, Dagres N, et al. ESC Guidelines for the diagnosis and management of atrial fibrillation developed in collaboration with the European Association of Cardio-Thoracic Surgery (EACTS). Eur Heart J 2021; 42: 373-498.

https://doi.org/10.1093/eurheartj/ehaa612

26. Bertaglia E, Blank B, Blomström-Lundqvist C, et al. Atrial highrate episodes: prevalence, stroke risk, implications for management, and clinical gaps in evidence. Europace 2019; 21: 1459-67.

https://doi.org/10.1093/europace/euz172

27. Safak E, D Ancona G, Kaplan H, et al. New generation cardioverter-defibrillator lead with a floating atrial sensing dipole: longterm performance. Pacing Clin Electrophysiol 2018; 41: 128-35.

https://doi.org/10.1111/pace.13256

28. Brignole M, Auricchio A, Baron-Esquivias G, et al. ESC Guidelines on cardiac pacing and cardiac resynchronization therapy: the Task Force on cardiac pacing and resynchronization therapy of the European Society of Cardiology (ESC). Developed in collaboration with the European Heart Rhythm Association (EHRA). Eur Heart J 2013; 34: 2281-329. https://doi.org/10.1093/europace/eut206

29. Kusumoto FM, Schoenfeld MH, Barrett C, et al. ACC/AHA/HRS Guideline on the Evaluation and Management of Patients With Bradycardia and Cardiac Conduction Delay: a Report of the American College of Cardiology/American Heart Association Task Force on Clinical Practice Guidelines and the Heart Rhythm Society. Circulation 2019; 140: e382-482. https://doi.org/10.1016/j.jacc.2018.10.043 30. Ponikowski P, Voors AA, Anker SD, et al. ESC Guidelines for the diagnosis and treatment of acute and chronic heart failure: the Task Force for the diagnosis and treatment of acute and chronic heart failure of the European Society of Cardiology (ESC) Developed with the special contribution of the Heart Failure Association (HFA) of the ESC. Eur Heart J 2016; 37: 2129-200.

https://doi.org/10.1093/eurheartj/ehw128 